\begin{tabular}{|c|c|}
\hline Title & Pall ladium-Catalyzed Germylation of A ryl Bromides and A ryI Triflates U sing Hexamethy Idigermane \\
\hline Author(s) & Komami, Narumi; Matsuoka, Keitaro; Y oshino, Tatsuhiko; Matsunaga, Shigeki \\
\hline Citation & $\begin{array}{l}\text { Synthesis stuttgart, 50(10), 2067-2075 } \\
\text { https://doi.org/10.1055/s0037-1609301 }\end{array}$ \\
\hline Issue Date & $2018-05$ \\
\hline Doc URL & http:/hdl.handle.net/2115/74516 \\
\hline Rights & @2018 Georg Thieme V erlag \\
\hline Type & article (author version) \\
\hline File Information & WoS_84687_Y oshino.pdf \\
\hline
\end{tabular}

Instructions for use 


\section{Palladium-catalyzed Germylation of Aryl Bromides and Aryl Triflates Using Hexamethyldigermane}

\author{
Narumi Komami \\ Keitaro Matsuoka \\ Tatsuhiko Yoshino* \\ Shigeki Matsunaga* \\ Faculty of Pharmaceutical Sciences, Hokkaido University, Kita- \\ 12 Nishi-6, Sapporo, Hokkaido 060-0812, Japan. \\ * indicates the main/corresponding author. \\ tyoshino@pharm.hokudai.ac.jp \\ smatsuna@pharm.hokudai.ac.jp
}
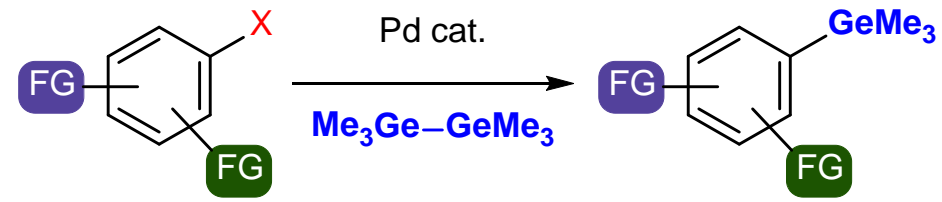

$\mathrm{X}=\mathrm{Br}$ and OTf

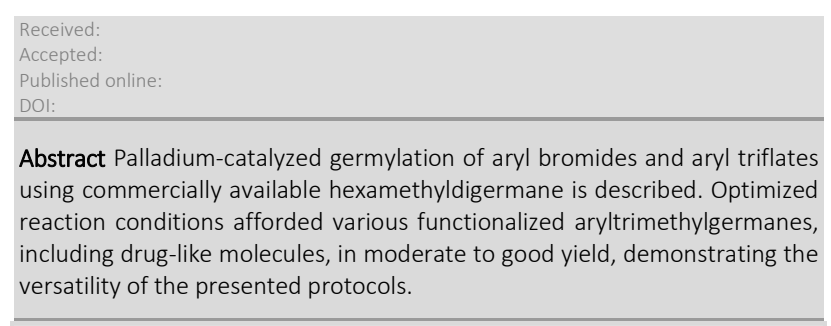

Key words palladium catalysis, germylation, digermane, aryl bromide, aryl triflate

Organosilicon ${ }^{1}$ and organotin ${ }^{2}$ compounds are useful reagents in organic synthesis and can be applied to a variety of synthetic transformations, including transition metal-catalyzed crosscoupling reactions. Organogermanium compounds, however, have attracted much less attention. Germanium is located between silicon and tin in the periodic table, and the properties of a C-Ge bond are intermediate between a C-Si bond and a CSn bond. ${ }^{3}$ Arylgermanes are expected to be more reactive toward electrophiles ${ }^{4}$ than arylsilanes due to the stronger $\beta$ effect from the $\mathrm{C}-\mathrm{Ge}$ bond compared with the C-Si bond. ${ }^{5}$ Organotin compounds are more reactive, but highly toxic. ${ }^{6}$ Therefore, arylgermanes are potentially attractive synthetic intermediates, but only a limited number of synthetic reactions using arylgermanes are reported.,3b-d,7,8 This is in part due to the high cost of germanium, but the lack of the general methods to prepare arylgermanes is also an important issue. Nucleophilic substitution of halogermanes by aryllithium or Grignard reagents is the most reliable method for accessing arylgermanes. ${ }^{3 b}$ These highly reactive organometallic reagents are, however, incompatible with sensitive functional groups.

Transition metal-catalyzed silylation of aryl (pseudo)halides using disilanes ${ }^{9}$ or hydrosilanes ${ }^{10}$ has been extensively investigated over the last several decades for synthesizing

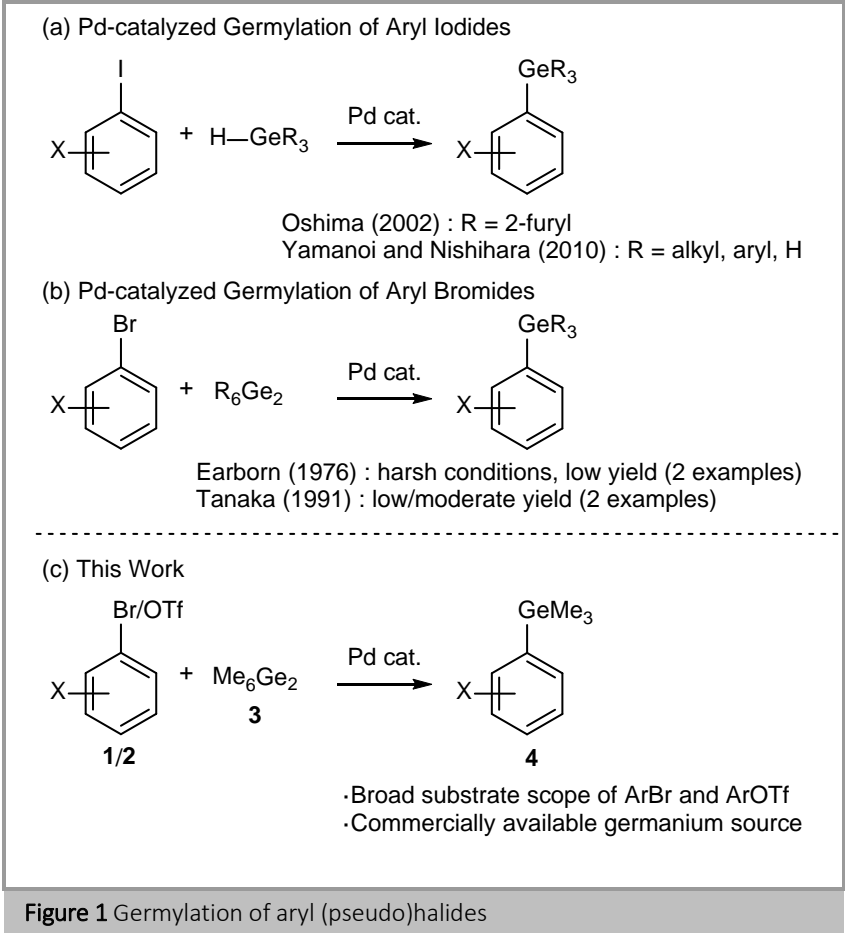

arylsilanes without using aryllithium or Grignard reagents. On the other hand, studies of transition metal-catalyzed germylation of aryl halides are scarce, $8 \mathrm{c}, 9 \mathrm{~b}, 10 \mathrm{~h}, \mathrm{k}, 11$ although such reactions enable the direct synthesis of functionalized arylgermanes. Oshima achieved Pd-catalyzed germylation of aryl iodides using tri(2-furyl)germane, (Figure 1a), ,c but electron-deficient aryl iodides were not investigated, and an aryl bromide was unreactive. Yamanoi and Nishihara reported general conditions for Pd-catalyzed coupling reactions of various aryl iodides and hydrogermanes (Figure 1a).10k In contrast to aryl iodides, less reactive aryl bromides are still 
<smiles></smiles>

$1 \mathrm{a}$
$2 a$

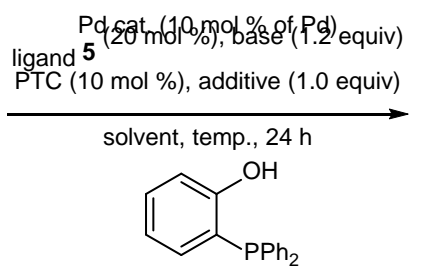

5

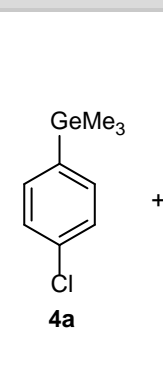

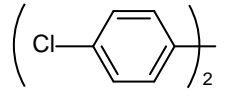

7

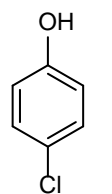

8

9

\begin{tabular}{|c|c|c|c|c|c|c|c|c|c|}
\hline Entry & Substrate & Pd cat. & Solvent & Base & PTC & Additive & Temp. $\left({ }^{\circ} \mathrm{C}\right)$ & $\%$ Yield of $4 a^{b}$ & Raito of $1 a$ or $2 a: 4 a: 6: 7: 8: 9^{c}$ \\
\hline 1 & $1 a$ & {$\left[\mathrm{PdCl}(\text { allyl) }]_{2}\right.$} & $\mathrm{THF} / \mathrm{H}_{2} \mathrm{O}$ & $\mathrm{NaOH}$ & $\mathrm{Bu}_{4} \mathrm{NBr}$ & - & 100 & 44 & $2: 75: 4: 18: 0: 0$ \\
\hline 2 & 1a & {$\left[\mathrm{PdCl}(\text { allyl) }]_{2}\right.$} & toluene/ $\mathrm{H}_{2} \mathrm{O}$ & $\mathrm{NaOH}$ & $\mathrm{Bu}_{4} \mathrm{NBr}$ & - & 100 & 60 & $3: 80: 13: 3: 1: 0$ \\
\hline 3 & $1 \mathrm{a}$ & $\mathrm{Pd}_{2}(\mathrm{dba})_{3}$ & toluene $/ \mathrm{H}_{2} \mathrm{O}$ & $\mathrm{NaOH}$ & $\mathrm{Bu}_{4} \mathrm{NBr}$ & - & 100 & 39 & $0: 65: 12: 21: 2: 0$ \\
\hline 4 & $1 a$ & $\mathrm{Pd}(\mathrm{OAc})_{2}$ & toluene $/ \mathrm{H}_{2} \mathrm{O}$ & $\mathrm{NaOH}$ & $\mathrm{Bu}_{4} \mathrm{NBr}$ & - & 100 & 62 & $0: 73: 3: 23: 1: 0$ \\
\hline 5 & $1 \mathrm{a}$ & $\mathrm{Pd}(\mathrm{OAc})_{2}$ & toluene $/ \mathrm{H}_{2} \mathrm{O}$ & $\mathrm{KOtBu}$ & $\mathrm{Bu}_{4} \mathrm{NBr}$ & - & 100 & 48 & $0: 66: 2: 32: 1: 0$ \\
\hline 6 & $1 a$ & $\mathrm{Pd}(\mathrm{OAc})_{2}$ & toluene $/ \mathrm{H}_{2} \mathrm{O}$ & KOAC & $\mathrm{Bu}_{4} \mathrm{NBr}$ & - & 100 & 47 & $0: 67: 25: 6: 2: 0$ \\
\hline 7 & 1a & $\mathrm{Pd}(\mathrm{OAc})_{2}$ & toluene/ $\mathrm{H}_{2} \mathrm{O}$ & $\mathrm{Cs}_{2} \mathrm{CO}_{3}$ & $\mathrm{Bu}_{4} \mathrm{NBr}$ & - & 100 & 77 & $0: 89: 6: 4: 1: 0$ \\
\hline 9 & $1 \mathrm{a}$ & $\mathrm{Pd}(\mathrm{OAc})_{2}$ & toluene $/ \mathrm{H}_{2} \mathrm{O}$ & $\mathrm{Cs}_{2} \mathrm{CO}_{3}$ & $\mathrm{Et}_{4} \mathrm{NHCO}_{3}$ & - & 100 & $93(86)^{d}$ & $0: 92: 8: 0: 0: 0$ \\
\hline $10^{e}$ & $1 a$ & $\mathrm{Pd}(\mathrm{OAc})_{2}$ & toluene $/ \mathrm{H}_{2} \mathrm{O}$ & $\mathrm{Cs}_{2} \mathrm{CO}_{3}$ & $\mathrm{Et}_{4} \mathrm{NHCO}_{3}$ & - & 100 & 63 & $0: 71: 3: 0: 26: 0$ \\
\hline 11 & $2 a$ & $\mathrm{Pd}(\mathrm{OAc})_{2}$ & toluene $/ \mathrm{H}_{2} \mathrm{O}$ & $\mathrm{Cs}_{2} \mathrm{CO}_{3}$ & $\mathrm{Et}_{4} \mathrm{NHCO}_{3}$ & - & 100 & 0 & $99: 0: 0: 0: 0: 1$ \\
\hline 12 & $2 a$ & $\mathrm{Pd}(\mathrm{OAc})_{2}$ & toluene & $\mathrm{Cs}_{2} \mathrm{CO}_{3}$ & $\mathrm{Et}_{4} \mathrm{NHCO}_{3}$ & - & 100 & 11 & $25: 16: 0: 0: 16: 43$ \\
\hline 13 & $2 a$ & $\mathrm{Pd}(\mathrm{OAc})_{2}$ & toluene & $\mathrm{Cs}_{2} \mathrm{CO}_{3}$ & $\mathrm{Et}_{4} \mathrm{NHCO}_{3}$ & $\mathrm{LiCl}$ & 100 & 13 & $61: 11: 0: 0: 5: 23$ \\
\hline 14 & $2 a$ & $\mathrm{Pd}(\mathrm{OAc})_{2}$ & toluene & $\mathrm{Cs}_{2} \mathrm{CO}_{3}$ & $\mathrm{Et}_{4} \mathrm{NHCO}_{3}$ & $\mathrm{LiBr}$ & 100 & 9 & $94: 5: 1: 0: 0: 0$ \\
\hline 15 & $2 a$ & $\mathrm{Pd}(\mathrm{OAc})_{2}$ & toluene & $\mathrm{Cs}_{2} \mathrm{CO}_{3}$ & $\mathrm{Et}_{4} \mathrm{NHCO}_{3}$ & $\mathrm{Bu}_{4} \mathrm{NCl}$ & 100 & 2 & $94: 2: 0: 0: 0: 4$ \\
\hline 16 & $2 a$ & $\mathrm{Pd}(\mathrm{OAc})_{2}$ & toluene & $\mathrm{Cs}_{2} \mathrm{CO}_{3}$ & $\mathrm{Et}_{4} \mathrm{NHCO}_{3}$ & $\mathrm{Bu}_{4} \mathrm{NBr}$ & 100 & 8 & $88: 7: 0: 0: 0: 5$ \\
\hline 18 & $2 a$ & $\mathrm{Pd}(\mathrm{OAc})_{2}$ & toluene & $\mathrm{Cs}_{2} \mathrm{CO}_{3}$ & $\mathrm{Et}_{4} \mathrm{NHCO}_{3}$ & $\mathrm{Et}_{4} \mathrm{NCl}$ & 100 & 35 & $7: 54: 1: 0: 9$ \\
\hline 19 & $2 a$ & $\mathrm{Pd}(\mathrm{OAc})_{2}$ & toluene & $\mathrm{Cs}_{2} \mathrm{CO}_{3}$ & $\mathrm{Et}_{4} \mathrm{NHCO}_{3}$ & $\mathrm{Et}_{4} \mathrm{NBr}$ & 100 & 49 & $30: 42: 0: 2: 14: 12$ \\
\hline 20 & $2 a$ & $\mathrm{Pd}(\mathrm{OAc})_{2}$ & toluene & $\mathrm{Cs}_{2} \mathrm{CO}_{3}$ & $\mathrm{Et}_{4} \mathrm{NHCO}_{3}$ & $\mathrm{Et}_{4} \mathrm{NBr}$ & 120 & 77 & $2: 59: 0: 0: 27: 12$ \\
\hline 21 & $2 a$ & $\mathrm{Pd}(\mathrm{OAC})_{2}$ & toluene & $\mathrm{Cs}_{2} \mathrm{CO}_{3}$ & - & $\mathrm{Et}_{4} \mathrm{NBr}$ & 120 & $85(83 \%)^{d}$ & $1: 66: 2: 0: 24: 7$ \\
\hline
\end{tabular}

${ }^{\mathrm{a}}$ The reactions were performed using $1 \mathrm{a}$ or $2 \mathrm{a}(0.10 \mathrm{mmol}), 3(0.12 \mathrm{mmol})$, Pd cat. (10 mol \% of Pd), ligand $5(0.02 \mathrm{mmol}, 20 \mathrm{~mol} \%), \mathrm{PTC}(0.01 \mathrm{mmol}, 10 \mathrm{~mol} \%)$, and base $(0.12$ $\mathrm{mmol})$ in $\mathrm{THF} / \mathrm{H}_{2} \mathrm{O}=1: 1$ or toluene/ $\mathrm{H}_{2} \mathrm{O}=1: 1$ or toluene $(0.5 \mathrm{~mL})$ for 24 h unless otherwise noted.

${ }^{b}$ Determined by GC/MS analysis using pentadecane as an internal standard.

${ }^{\mathrm{c}}$ The radio of the TIC area in GC/MS analysis.

d Isolated yield in $0.50 \mathrm{mmol}$ scale.

${ }^{\mathrm{e}} \mathrm{PPh}_{3}$ (0.02 mmol, $20 \mathrm{~mol} \%$ ) was used as a ligand instead of 5

difficult substrates for germylation (Figure 1b). Earborn reported Pd-catalyzed germylation of aryl bromides with hexaethyldigermane, but the reactions required harsh conditions $\left(140-180{ }^{\circ} \mathrm{C}\right)$ and resulted in a low yield. ${ }^{9 \mathrm{~b}}$ Tanaka reported Pd-catalyzed germylation of bromobenzene and 2,5dibromothiophene, but moisture sensitive dichlorotetramethyldigermane was required, and the results were rather complicated due to halogen exchange. ${ }^{11}$ To date, general and practical conditions for transition metal-catalyzed germylation of aryl bromides and aryl triflates have not been reported.

In this article, we report Pd-catalyzed germylation of aryl bromides $\mathbf{1}$ and aryl triflates $\mathbf{2}$ using commercially available hexamethyldigermane $\mathbf{3}$ (Figure 1c).

We initiated our investigation by optimizing the reaction conditions for germylation of aryl bromide 1a using hexamethyldigermane 3 (Table 1, entries 1-10). We selected the reaction conditions of Pd-catalyzed silylation of aryl halides with hexamethyldisilane reported by Shirakawa and Hiyama $9 \mathrm{~g}$ as the initial conditions (entries 1,2). These conditions afforded the desired germylated arene $\mathbf{4 a}$ in moderate yield along with several byproducts. GC/MS analysis revealed the formation of reduced product $\mathbf{6}$, biaryl $\mathbf{7}$, and unidentified products bearing an allyl or propenyl group. We next investigated other palladium sources using toluene $/ \mathrm{H}_{2} \mathrm{O}$ as the solvent to circumvent incorporation of the C3 units derived from $[\mathrm{PdCl}(\text { allyl })]_{2}$. While $\mathrm{Pd}_{2}(\mathrm{dba})_{3}$ exhibited inferior catalytic activity (entry 3 ), the use of $\mathrm{Pd}(\mathrm{OAc})_{2}$ resulted in $62 \%$ yield (entry 4). In these cases, incorporation of the C3 unit was avoided, but a significant amount of $\mathbf{7}$ was produced. Several bases and phase transfer catalysts (PTC) were then screened to improve the selectivity (entries 5-9), and $\mathrm{Cs}_{2} \mathrm{CO}_{3}$ and $\mathrm{Et}_{4} \mathrm{NHCO}_{3}$ were the most effective for providing $\mathbf{4 a}$ in $93 \%$ yield, with only a tiny amount of 6 (entry 9). We performed a control experiment using $\mathrm{PPh}_{3}$ as a ligand instead of 5 (entry 10). The reaction unexpectedly proceeded with moderate yield, but a relatively large amount of phenyl(trimethyl)germane 8 was observed. This byproduct would be formed by reduction of $\mathbf{4 a}$ or an aryl-aryl exchange between an arylpalladium intermediate and $\mathrm{PPh}_{3}$ during the catalytic process. ${ }^{12}$ We next investigated germylation of aryl triflate $2 a$ (entries 11-21). The optimized conditions for aryl bromide 1a in entry 9 afforded no products, and 2a remained intact (entry 11). The use of toluene as the sole solvent provided the desired product $\mathbf{3}$, but the yield was low and a significant amount of $\mathbf{9}$ was observed 


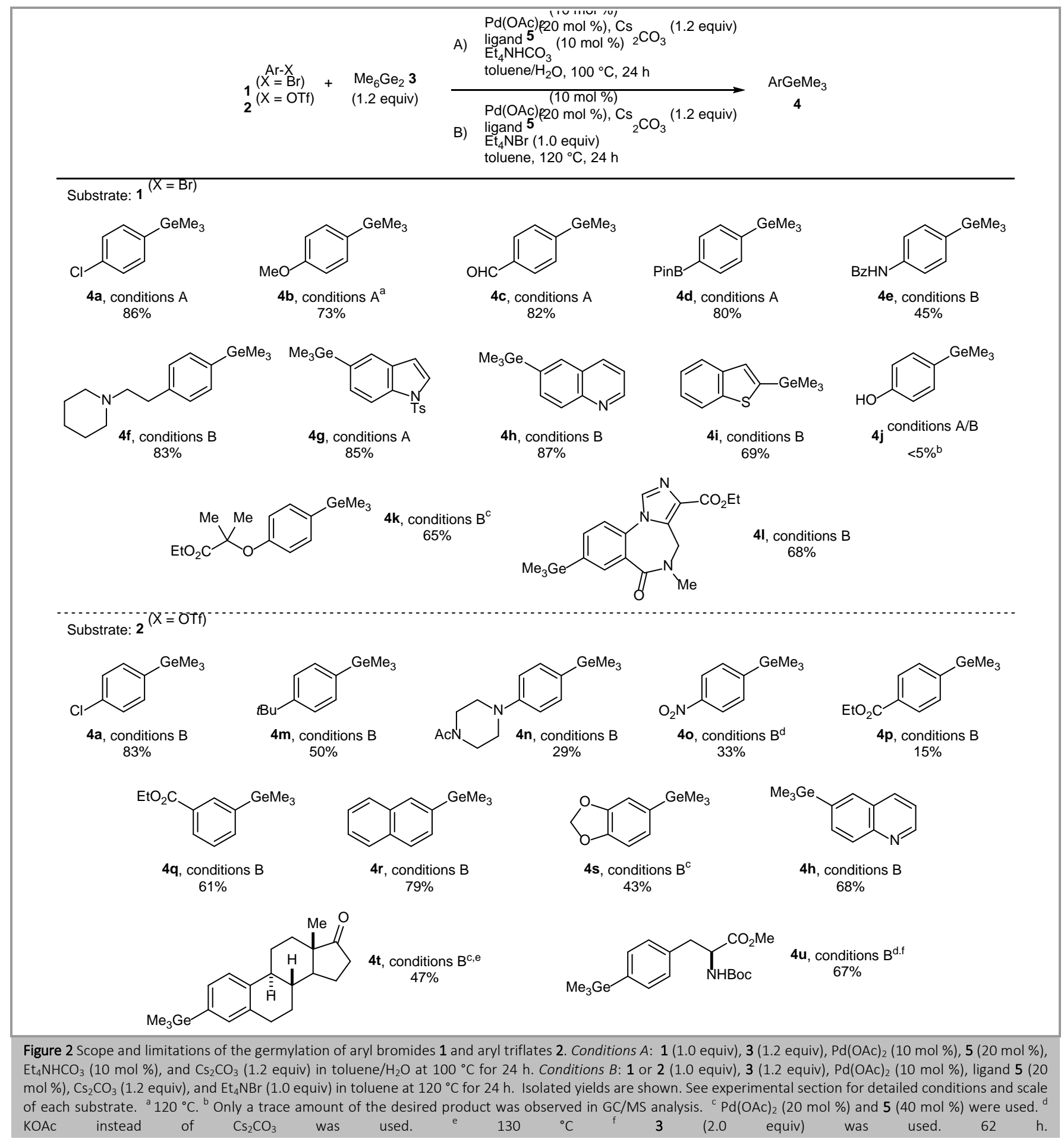

(entry 12). We speculated the lower reactivity of $\mathbf{2 a}$ compared with 1a might be due to the absence of a halide ion in the reaction, and several halide sources were screened as potential additives (entries 13-19). The addition of one equivalent of $\mathrm{Et}_{4} \mathrm{NBr}$ was found to be effective, and the yield was improved to $49 \%$ (entry 19). Raising the reaction temperature to $120{ }^{\circ} \mathrm{C}$ further improved the yield (entry 20). Finally, the conditions without $\mathrm{Et}_{4} \mathrm{NHCO}_{3}$ resulted in a slightly better yield (entry 21), and were determined to be the optimal conditions for $\mathbf{2 a}$. Although a significant amount of 8 was observed at $120^{\circ} \mathrm{C}$, the yield of $\mathbf{4 a}$ based on an internal standard was high (entries 20 and 21), indicating that 8 was derived from ligand 5 rather than $\mathbf{2 a}$ or $\mathbf{4 a}$ in these cases.

The scope and limitations of the optimized conditions for germylation are summarized in Figure 2. Both electron-deficient and electron-rich aryl bromides afforded the desired products in good yield (4a, 4b). Various functional groups were well tolerated, providing germylated building blocks that are useful for further transformation (4c-4f). Heteroaryl bromides were reactive to give the corresponding germylated products $(\mathbf{4 g}, \mathbf{4 h}$, 4i). The conditions optimized for aryl triflates (Conditions $B$ ) were more effective for less reactive aryl bromides to afford $\mathbf{4 f}$, $\mathbf{4 h}$ and $\mathbf{4 i}$. 4-Bromophenol $\mathbf{1 j}$, however, failed to give the 
germylated product $\mathbf{4 j}$, and phenol was detected as a major product under both reaction conditions. Germylated drug-like structures $\left(\mathbf{4} \mathbf{k},{ }^{13} \mathbf{4 l}^{14}\right)$ were accessible from the corresponding aryl bromides under Conditions $B$. In addition to aryl bromides, various types of aryl triflates afforded the desired germylated arenes. Electron-rich arenes such as $\mathbf{2 n}$ and $2 \mathbf{s}$ exhibited low reactivity (4n, 4s), while highly electron-deficient substrates resulted in low yields due to fast hydrolysis of the sulfonate group (4o, 4p). In some cases, the use of KOAc instead of $\mathrm{Cs}_{2} \mathrm{CO}_{3}$ was beneficial for avoiding the hydrolysis $(\mathbf{4 o}, \mathbf{4 u})$. Moderately electron-deficient aryl triflates were good substrates, and the products were obtained in good yield $(\mathbf{4 a}, \mathbf{4 q}, \mathbf{4 r}, \mathbf{4 h})$ under the standard conditions. The triflate of estrone $2 \mathrm{t}$ exhibited low reactivity, but moderate yield was obtained using $20 \mathrm{~mol} \%$ of $\mathrm{Pd}(\mathrm{OAc})_{2}(\mathbf{4 t})$.

We also investigated germylation of aryl iodide $\mathbf{1 0}$ under the optimized conditions for aryl bromides (Scheme 1). The conditions for aryl bromides were effective to provide $4 \mathbf{a}$ in $95 \%$ yield at $80^{\circ} \mathrm{C}$, but the lower reaction temperature resulted in lower conversion.

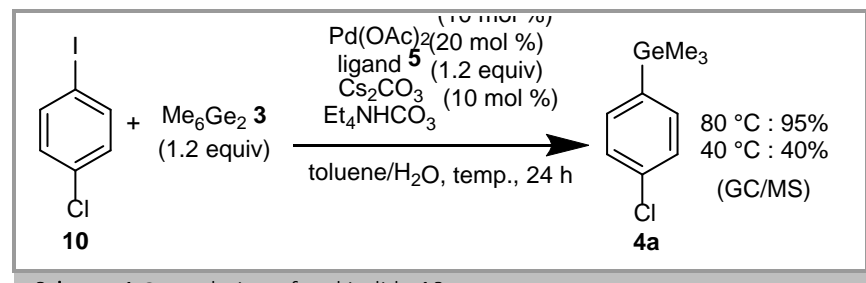

Scheme 1 Germylation of aryl iodide 10

When $\beta$-bromostyrene was used as a substrate, both Conditions $A$ and Conditions $B$ in Figure 2 afforded a dimerized product as a major product (see Supporting Information). Thus, the developed conditions were not suitable for germylation of alkenyl bromides.

The exact catalytic cycle was not elucidated, but a plausible cycle comprises oxidative addition of $\mathbf{1}$ or $\mathbf{2}$ to $\operatorname{Pd}(0)$, transmetalation with digermane $\mathbf{3}$, and reductive elimination to release arylgermane 4 . The use of $\mathrm{PPh}_{3}$ as a ligand also afforded the product in moderate yield (Table 1, entry 10), and therefore a hydroxy group of $\mathbf{5}$ would only have minor effects for the desired catalytic cycle, in contrast to the dramatic ligand effects observed in silylation.9g The role of $\mathrm{Et}_{4} \mathrm{NBr}$ in germylation of aryl triflates was unclear. A tetraethylammonium ion might be important rather than a bromide ion (Table 1, entries 13-19).

In summary, we developed general conditions for the germylation of aryl bromides $\mathbf{1}$ and aryl triflates $\mathbf{2}$ using hexamethyldigermane $\mathbf{3}$ under palladium catalysis. Various functionalized substrates, including drug-like molecules, afforded the germylated products in moderate to good yield, demonstrating the versatility of the presented protocols. These methods enable easy access to functionalized arylgermanes, and may encourage further investigation of the properties and reactivity of arylgermane derivatives.

\section{The experimental section has no title; please leave this line here.}

\section{Procedures}

General: Reported melting points were uncorrected. Infrared (IR) spectra were recorded on a JASCO FT/IR-5300 spectrophotometer and absorbance bands are reported in wave numbers $\left(\mathrm{cm}^{-1}\right)$. NMR spectra were recorded on JEOL JNM-ECS400 spectrometers operating at 391.78 $\mathrm{MHz}$ for ${ }^{1} \mathrm{H}$ NMR and $98.52 \mathrm{MHz}$ for ${ }^{13} \mathrm{C}$ NMR, JEOL JNM-ECX400 spectrometers operating at $395.88 \mathrm{MHz}$ for $1 \mathrm{H} \mathrm{NMR}$ and $99.55 \mathrm{MHz}$ for ${ }^{13} \mathrm{C}$ NMR, and JNM-ECA500 spectrometers operating at $500.16 \mathrm{MHz}$ for ${ }^{1} \mathrm{H}$ NMR and $125.77 \mathrm{MHz}$ for ${ }^{13} \mathrm{C}$ NMR. Chemical shifts were reported in the scale relative to TMS (0.00 ppm for $\left.{ }^{1} \mathrm{H} \mathrm{NMR}\right), \mathrm{CHCl}_{3}\left(7.26 \mathrm{ppm}\right.$ for ${ }^{1} \mathrm{H}$ $\mathrm{NMR}), \mathrm{CDCl}_{3}$ (77.0 ppm for $\left.{ }^{13} \mathrm{C} \mathrm{NMR}\right), \mathrm{C}_{6} \mathrm{HD}_{5}$ (7.15 ppm for $\left.{ }^{1} \mathrm{H} \mathrm{NMR}\right)$ and $\mathrm{C}_{6} \mathrm{D}_{6}$ (128.06 ppm for ${ }^{13} \mathrm{C} \mathrm{NMR}$ ) as an internal reference, respectively. ESI mass spectra were measured on JEOL JMS-T100LCP spectrometer. Silica gel column chromatography was performed with Kanto Silica gel $60 \mathrm{~N}$ (40-50 mesh). Gel permeation chromatography was performed with YMC LC-forte/ $\mathrm{R}$ using $\mathrm{CHCl}_{3}$ as an eluent. Commercially available THF, toluene (Wako Ltd., deoxidized grade) were used without further manipulation unless otherwise stated. All aryl Triflates $\mathbf{2}$ were prepared from corresponding commercially available phenol. Aryl bromides 1a, 1b, 1c, 1d, 1h, 1i were commercially available and distilled under reduced pressure or recrystallized before use. 1-(4Bromophenethyl)piperidine 1f,[15] 5-bromo-1-tosyl-1H-indole 1g,[16] 2bromobenzo[b] thiophene $\mathbf{1 i},{ }^{[17]}$ and ethyl 8-bromo-5-methyl-6-oxo-5,6dihydro-4H-benzo[f]imidazo[1,5-a][1,4]diazepine-3-carboxylate $\quad \mathbf{1 k}^{[14]}$ were synthesized according to the literature. Structures of bromides $\mathbf{1}$ and aryl triflates $\mathbf{2}$ are listed in Figure S1 in Supporting Information. Hexamethyldigermane $\mathbf{3}$ was purchased from Sigma-Aldrich and used as received. All other reagents were commercially available and used as received.

\section{General Procedure for Germylation of Aryl Bromides and Triflates}

Conditions A: To a screw vial with a septum cap were added aryl bromide 1 (0.50 mmol), $\mathrm{Pd}(\mathrm{OAc})_{2}(11.2 \mathrm{mg}, 0.05 \mathrm{mmol}, 10 \mathrm{~mol} \%)$, ligand 5 (27.8 mg, $0.10 \mathrm{mmol}, 20 \mathrm{~mol} \%$ ), $\mathrm{Cs}_{2} \mathrm{CO}_{3}$ (195.5 mg, $0.60 \mathrm{mmol}$, 1.2 equiv.), $\mathrm{Et}_{4} \mathrm{NHCO}_{3}(9.5 \mathrm{mg}, 0.05 \mathrm{mmol}, 10 \mathrm{~mol} \%)$, hexamethyldigermane $3(120 \mu \mathrm{L}, 0.60 \mathrm{mmol}, 1.2$ equiv.) and toluene $(1.25 \mathrm{~mL})$ under Ar atmosphere in a glove box. The vial was capped and removed from the glove box, and then $\mathrm{H}_{2} \mathrm{O}(1.25 \mathrm{~mL})$ was injected via syringe. The vial was heated at $100{ }^{\circ} \mathrm{C}$ for $24 \mathrm{~h}$ with stirring. After cooled to room temperature, the organic layer was separated, and the aqueous layer was extracted with EtOAc $(3 \mathrm{~mL} \times 3)$. The combined organic layers were washed with brine $(3 \mathrm{~mL})$, dried over $\mathrm{Na}_{2} \mathrm{SO}_{4}$. Filtration and evaporation gave a crude product, which was purified by silica gel column chromatography to give a corresponding product 4 .

Conditions B: To a dried screw capped vial were added aryl bromide $\mathbf{1}$ or aryl triflate $2(0.50 \mathrm{mmol}), \mathrm{Pd}(\mathrm{OAc})_{2}(11.2 \mathrm{mg}, 0.05 \mathrm{mmol}, 10 \mathrm{~mol} \%)$, Ligand 5 (27.8 mg, $0.10 \mathrm{mmol}, 20 \mathrm{~mol} \%$ ), $\mathrm{Cs}_{2} \mathrm{CO}_{3}(195.5 \mathrm{mg}, 0.60 \mathrm{mmol}$, 1.2 equiv.), $\quad \mathrm{Et}_{4} \mathrm{NBr} \quad(105.1 \mathrm{mg}, \quad 0.5 \mathrm{mmol}, 1.0$ equiv.), hexamethyldigermane 3 ( $120 \mu \mathrm{L}, 0.60 \mathrm{mmol}, 1.2$ equiv.) and toluene ( 2.5 $\mathrm{mL}$ ) under Ar atmosphere in a glove box. The vial was capped and heated at $120^{\circ} \mathrm{C}$ for $24 \mathrm{~h}$ with stirring. After cooled to room temperature, $\mathrm{H}_{2} \mathrm{O}(2$ $\mathrm{mL}$ ) was added. After dilution with EtOAc, the organic layer was separated, and the aqueous layer was extracted with EtOAc $(3 \mathrm{~mL} \times 3)$. The combined organic layers were washed with brine $(3 \mathrm{~mL})$, and dried over $\mathrm{Na}_{2} \mathrm{SO}_{4}$. Filtration and evaporation gave a crude product, which was purified by silica gel column chromatography to give a corresponding product 4.

\section{(4-Chlorophenyl)trimethylgermane (4a)}

Conditions A using 1-bromo-4-chlorobenzene $1 \mathrm{a}(0.50 \mathrm{mmol})$ and purification of the crude product by silica gel column chromatography (hexane) followed by gel permeation chromatography afforded $\mathbf{4 a}$ as a colorless oil ( $98.6 \mathrm{mg}, 86 \%$ yield).

Conditions B using 4-chlorophenyl trifluoromethanesulfonate 2a $(0.50$ $\mathrm{mmol}$ ) and purification of the crude product by silica gel column chromatography (hexane) afforded $\mathbf{4 a}$ as a colorless oil $(95.1 \mathrm{mg}, 83 \%$ yield).

TLC: $\mathrm{R}_{f} 0.75$ (hexane)

IR (neat): 2972, 2907,1481, 1381, 1238, 1077, 1015, 825, 602, $571 \mathrm{~cm}^{-1}$ 
${ }^{1} \mathrm{H}$ NMR (400 MHz, $\left.\mathrm{CDCl}_{3}\right): \delta=7.41-7.38(\mathrm{~m}, 2 \mathrm{H}), 7.33-7.30(\mathrm{~m}, 2 \mathrm{H})$, $0.38(\mathrm{~s}, 9 \mathrm{H})$

${ }^{13} \mathrm{C}$ NMR $\left(100 \mathrm{MHz}, \mathrm{CDCl}_{3}\right): \delta=140.8,134.5,134.3,128.1,-1.83$ HRMS (EI): $m / z\left(\mathrm{M}^{+}\right)$calcd for $\mathrm{C}_{9} \mathrm{H}_{13} \mathrm{Cl}^{70} \mathrm{Ge}: 225.9948$; found: 225.9945

\section{(4-Methoxyphenyl)trimethylgermane (4b)}

Conditions A using 1-bromo-4-methoxybenzene $\mathbf{1 b}$ at $120{ }^{\circ} \mathrm{C}$ and purification of the crude product by silica gel column chromatography (hexane/EtOAc $=20: 1)$ afforded $\mathbf{4 b}$ as a colorless oil $(82.0 \mathrm{mg}, 73 \%$ yield).

TLC: $\mathrm{R}_{f} 0.59$ (hexane/EtOAc $=8: 1$ )

IR (neat): 2969, 2905, 1592, 1568, 1499, 1461, 1279, 1246, 1180, 1094, $1032,823,599,567 \mathrm{~cm}^{-1}$

${ }^{1} \mathrm{H}$ NMR (400 MHz, $\left.\mathrm{CDCl}_{3}\right): \delta=7.42-7.37(\mathrm{~m}, 2 \mathrm{H}), 6.94-6.90(\mathrm{~m}, 2 \mathrm{H})$, $3.81(\mathrm{~s}, 3 \mathrm{H}), 0.36(\mathrm{~s}, 9 \mathrm{H})$

${ }^{13} \mathrm{C}$ NMR $\left(100 \mathrm{MHz}, \mathrm{CDCl}_{3}\right): \delta=159.8,134.1,133.2,113.7,55.0,-1.66$ HRMS (EI): $m / z\left(\mathrm{M}^{+}\right)$calcd for $\mathrm{C}_{10} \mathrm{H}_{16}{ }^{70} \mathrm{GeO}: 222.0444$; found: 222.0444

\section{4-(Trimethylgermyl)benzaldehyde (4c)}

Conditions A using 4-bromobenzaldehyde 1c and purification of the crude product by silica gel column chromatography (hexane/EtOAc $=$ $30: 1$ to $20: 1$ ) followed by gel permeation chromatography afforded $\mathbf{4 c}$ as a colorless oil ( $91.2 \mathrm{mg}, 82 \%$ yield)

TLC: $\mathrm{R}_{f} 0.65$ (hexane/EtOAc $=5: 1$ )

IR (neat): 2979, 2911, 2825, 1703, 1594, 1211, 1172, 825, 679, 603, 571 $\mathrm{cm}^{-1}$

${ }^{1} \mathrm{H}$ NMR (400 MHz, $\left.\mathrm{CDCl}_{3}\right): \delta=10.01(\mathrm{~s}, 1 \mathrm{H}), 7.83(\mathrm{~d}, J=8.1 \mathrm{~Hz}, 2 \mathrm{H})$ $7.65(\mathrm{~d}, J=8.1 \mathrm{~Hz}, 2 \mathrm{H}), 0.43(\mathrm{~s}, 9 \mathrm{H})$

${ }^{13} \mathrm{C} \mathrm{NMR}\left(100 \mathrm{MHz}, \mathrm{CDCl}_{3}\right): \delta=192.7,151.9,136.1,133.5,128.8,-1.93$

HRMS (EI): $m / z\left(\mathrm{M}^{+}\right)$calcd for $\mathrm{C}_{10} \mathrm{H}_{14}{ }^{70} \mathrm{GeO}$ : 220.0287; found: 222.0286

Trimethyl(4-(4,4,5,5-tetramethyl-1,3,2-dioxaborolan-2yl)phenyl)germane (4d)

Conditions A using 2-(4-bromophenyl)-4,4,5,5-tetramethyl-1,3,2dioxaborolane 1d and purification of the crude product by silica gel column chromatography (hexane $/$ EtOAc $=20: 1$ ) $4 \mathbf{d}$ as a colorless oil (128.3 mg, 80\% yield).

TLC: $\mathrm{R}_{f} 0.73$ (hexane/EtOAc $=5: 1$ )

M.p.: $119.3-120.2^{\circ} \mathrm{C}$

IR (KBr): 2977, 1598, 1327, 1296, 1108, 859, 656, $602 \mathrm{~cm}^{-1}$

${ }^{1} \mathrm{H} \mathrm{NMR}\left(400 \mathrm{MHz}, \mathrm{CDCl}_{3}\right): \delta=7.78(\mathrm{~d}, J=8.2 \mathrm{~Hz}, 2 \mathrm{H}), 7.49(\mathrm{~d}, J=8.2 \mathrm{~Hz}$, $2 \mathrm{H}), 1.34(\mathrm{~s}, 12 \mathrm{H}), 0.38(\mathrm{~s}, 9 \mathrm{H})$

${ }^{13} \mathrm{C}$ NMR $\left(125 \mathrm{MHz}, \mathrm{CDCl}_{3}\right): \delta=146.6,134.0,132.3,83.7,24.8,-1.91$; the carbon directly attached to the boron atom was not detected.

HRMS (ESI): $m / z\left(\mathrm{M}+\mathrm{Na}^{+}\right.$) calcd for $\mathrm{C}_{15} \mathrm{H}_{25} \mathrm{~B}^{70} \mathrm{GeO}_{2} \mathrm{Na}$ : 340.1124; found: 340.1134

\section{$N$-(4-(Trimethylgermyl)phenyl)benzamide (4e)}

Conditions B using $N$-(4-bromophenyl)benzamide $\mathbf{1 e}$ and purification of the crude product by silica gel column chromatography (hexane $/$ EtOAc $=$ 10:1 to $5: 1$ ) afforded $4 \mathbf{e}$ as a colorless solid (70.1 $\mathrm{mg}$, $45 \%$ yield).

TLC: $\mathrm{R}_{f} 0.65$ (hexane/EtOAc $=2: 1$ )

M.p.: $114.6-115.3^{\circ} \mathrm{C}$

IR (KBr): 3311, 2972, 1578, 1525, 1504, 1388, 1322, 1285, 819, 720, 694 $593 \mathrm{~cm}^{-1}$

${ }^{1} \mathrm{H} \mathrm{NMR}\left(400 \mathrm{MHz}, \mathrm{CDCl}_{3}\right): \delta=7.90-7.85(\mathrm{~m}, J=2 \mathrm{H}), 7.76(\mathrm{brs}, 1 \mathrm{H}), 7.63$ (d, $J=8.2 \mathrm{~Hz}, 2 \mathrm{H}), 7.58-7.47(\mathrm{~m}, 5 \mathrm{H}), 0.39(\mathrm{~s}, 9 \mathrm{H})$

${ }^{13} \mathrm{C}$ NMR $\left(125 \mathrm{MHz}, \mathrm{CDCl}_{3}\right): \delta=165.8,138.4,138.0,134.9,133.7,131.8$, $128.7,127.0,119.7,-1.78$
HRMS (ESI): $m / z\left(\mathrm{M}+\mathrm{Na}^{+}\right)$calcd for $\mathrm{C}_{16} \mathrm{H}_{19} \mathrm{ON}^{70} \mathrm{GeNa}$ : 334.0601; found: 334.0603

\section{1-(4-(Trimethylgermyl)phenethyl)piperidine (4f)}

Conditions B using 1-(4-bromophenethyl)piperidine 1f (268 mg, 1.0 mmol) and purification of the crude product by silica gel column chromatography (hexane/EtOAc $=6: 1,3 \% \mathrm{Et}_{3} \mathrm{~N}$ ) afforded $\mathbf{4 f}$ as a yellow oil (255 mg, 83\% yield).

TLC: $\mathrm{R}_{f} 0.38$ (hexane/EtOAc $=6: 1,3 \% \mathrm{Et}_{3} \mathrm{~N}$ )

IR (neat): 2969, 2934, 2853, 2798, 1758, 1235, 1155, 1120, 1090, 823, $757,600,572 \mathrm{~cm}^{-1}$

${ }^{1} \mathrm{H} \mathrm{NMR}\left(400 \mathrm{MHz}, \mathrm{CDCl}_{3}\right): \delta=7.40(\mathrm{~d}, J=8.2 \mathrm{~Hz}, 2 \mathrm{H}), 7.20(\mathrm{~d}, J=8.2 \mathrm{~Hz}$, $2 \mathrm{H}), 2.83-2.77$ (m, $2 \mathrm{H}), 2.59-2.53(\mathrm{~m}, 2 \mathrm{H}), 2.51-2.44(\mathrm{~m}, 4 \mathrm{H}), 1.67-1.59$ (m, $4 \mathrm{H}), 1.50-1.42(\mathrm{~m}, 2 \mathrm{H}), 0.36(\mathrm{~s}, 9 \mathrm{H})$

${ }^{13} \mathrm{C} \mathrm{NMR}\left(125 \mathrm{MHz} \mathrm{CDCl}_{3}\right): \delta=140.6,139.5,132.9,128.3,61.3,54.5,33.5$, $25.9,24.4,-1.84$

HRMS (ESI): $m / z\left(M+\mathrm{H}^{+}\right)$calcd for $\mathrm{C}_{16} \mathrm{H}_{28} \mathrm{~N}^{70} \mathrm{Ge}$ : 304.1459; found: 304.1461

\section{Tosyl-5-(trimethylgermyl)-1H-indole (4g)}

Conditions A using 5-bromo-1-tosyl-1H-indole $\mathbf{1 g}$ and purification of the crude product by silica gel column chromatography (hexane $/$ EtOAc $=$ 10:1 to 8:1) and afforded $\mathbf{4 g}$ as a colorless solid (165 mg, 85\% yield).

TLC: $\mathrm{R}_{f} 0.50$ (hexane/EtOAc $=5: 1$ )

M.p. : $110.2-110.8^{\circ} \mathrm{C}$

IR (KBr): 3140, 3111, 2968, 2916, 1447, 1371, 1257, 1188, 1172, 1131, $1095,996,585,576 \mathrm{~cm}^{-1}$

${ }^{1} \mathrm{H} \mathrm{NMR}\left(500 \mathrm{MHz}, \mathrm{CDCl}_{3}\right): \delta=7.97(\mathrm{~d}, J=8.3 \mathrm{~Hz}, 1 \mathrm{H}), 7.77(\mathrm{~d}, J=8.3 \mathrm{~Hz}$, $2 \mathrm{H}), 7.63(\mathrm{~s}, 1 \mathrm{H}), 7.54(\mathrm{~d}, J=3.7 \mathrm{~Hz}, 1 \mathrm{H}), 7.39$ (dd, $J=8.3,4.2 \mathrm{~Hz}, 1 \mathrm{H})$, $7.22(\mathrm{~d}, J=8.3 \mathrm{~Hz}, 2 \mathrm{H}), 6.64(\mathrm{~d}, J=3.7 \mathrm{~Hz}, 1 \mathrm{H}), 2.34(\mathrm{~s}, 3 \mathrm{H}), 0.38(\mathrm{~s}, 9 \mathrm{H})$

${ }^{13} \mathrm{C}$ NMR $\left(125 \mathrm{MHz}, \mathrm{CDCl}_{3}\right): \delta=144.9,136.6,135.4,135.0,130.6,129.9$, $128.9,126.8,126.1,126.0,113.0,108.7,21.5,-1.62$

HRMS (ESI): $m / z\left(\mathrm{M}+\mathrm{Na}^{+}\right)$calcd for $\mathrm{C}_{18} \mathrm{H}_{21} \mathrm{O}_{2} \mathrm{~N}^{70} \mathrm{GeNaS}$ : 408.0428; found: 408.0442

\section{6-(Trimethylgermyl)quinoline $(4 \mathrm{~h})$}

Conditions A using 6-bromoquinoline $\mathbf{1 h}$ and purification of the crude product by silica gel column chromatography (hexane $/$ EtOAc $=5: 1$ ) afforded $\mathbf{4 h}$ as a colorless oil (107 $\mathrm{mg}$, 87\% yield).

Conditions B using quinolin-6-yl trifluoromethanesulfonate $\mathbf{2 h}$ and purification of the crude product by silica gel column chromatography (hexane/EtOAc $=5: 1$ ) afforded $4 \mathrm{~h}$ as a colorless oil ( $83.5 \mathrm{mg}, 68 \%$ yield). TLC: $\mathrm{R}_{f} 0.30$ (hexane/EtOAc $=4: 1$ )

IR (neat): 2970, 2906, 1564, 1491, 1341, 1237, 1071, 856, 831, 799, 771, $623,601,587,567 \mathrm{~cm}^{-1}$

${ }^{1} \mathrm{H}$ NMR (500 MHz, $\left.\mathrm{CDCl}_{3}\right): \delta=8.91(\mathrm{dd}, J=4.0,1.7 \mathrm{~Hz}, 1 \mathrm{H}), 8.15(\mathrm{~d}, J=$ $8.0 \mathrm{~Hz}, 1 \mathrm{H}), 8.08(\mathrm{~d}, J=8.0 \mathrm{~Hz}, 1 \mathrm{H}), 7.92(\mathrm{~s}, 1 \mathrm{H}), 7.82(\mathrm{dd}, J=8.0,1.1 \mathrm{~Hz}$, $1 \mathrm{H}), 7.40(\mathrm{dd}, J=8.0,4.0 \mathrm{~Hz}, 1 \mathrm{H}), 0.48(\mathrm{~s}, 9 \mathrm{H})$

${ }^{13} \mathrm{C}$ NMR $\left(125 \mathrm{MHz}, \mathrm{CDCl}_{3}\right): \delta=150.4,148.3,141.4,135.8,133.5,132.8$, $128.5,127.9,121.1,-1.77$

HRMS (ESI): $m / z\left(M+\mathrm{H}^{+}\right)$calcd for $\mathrm{C}_{12} \mathrm{H}_{16} \mathrm{~N}^{70} \mathrm{Ge}$ : 244.0520; found: 244.0523

\section{Benzo $[b]$ thiophen-2-yltrimethylgermane (4i)}

Conditions B using 2-Bromobenzo[b]thiophene 1i and purification of the crude product by silica gel column chromatography (hexane) followed by gel permeation chromatography afforded $\mathbf{4 i}$ as a colorless oil (87.1 $\mathrm{mg}, 69 \%$ yield).

TLC: $\mathrm{R}_{f} 0.67$ (hexane/EtOAc $=20: 1$ )

IR (neat): 3056, 2973, 2907, 1453, 1240, 945, 826, 761, 744, 726, 605, $574,561 \mathrm{~cm}^{-1}$

${ }^{1} \mathrm{H} \mathrm{NMR}\left(400 \mathrm{MHz}, \mathrm{CDCl}_{3}\right): \delta=7.87(\mathrm{~d}, J=7.7 \mathrm{~Hz}, 1 \mathrm{H}), 7.79(\mathrm{~d}, J=7.7 \mathrm{~Hz}$, $1 \mathrm{H}), 7.38$ (s, $1 \mathrm{H}), 7.35-7.26(\mathrm{~m}, 2 \mathrm{H}), 0.51(\mathrm{~s}, 9 \mathrm{H})$ 
${ }^{13} \mathrm{C} \mathrm{NMR}\left(100 \mathrm{MHz}, \mathrm{CDCl}_{3}\right): \delta=143.7,143.4,141.1,129.6,124.1,123.9$, $123.2,122.2,-0.53$

HRMS (EI): $m / z\left(\mathrm{M}^{+}\right)$calcd for $\mathrm{C}_{11} \mathrm{H}_{14}{ }^{70} \mathrm{GeS}$ : 248.0059; found: 248.0057

\section{Ethyl 2-(4-bromophenoxy)-2-methylpropanoate (1k)}

4-Bromophenol (519 mg, $3.0 \mathrm{mmol}$ ) and $\mathrm{Cs}_{2} \mathrm{CO}_{3}$ (2.44 g, $7.5 \mathrm{mmol}, 2.5$ equiv) were dissolved in anhydrous DMF $(10 \mathrm{~mL})$. The solution was stirred for $10 \mathrm{~min}$, and then ethyl-2-bromoisobutyrate $(1.17 \mathrm{~g}, 6.0 \mathrm{mmol}$, 2.0 equiv) was added. The resulting reaction mixture was stirred at $100{ }^{\circ} \mathrm{C}$ for $23 \mathrm{~h}$. After cooled to room temperature, the residue was taken up in EtOAc ( $50 \mathrm{~mL})$. The solution was successively washed with $\mathrm{H}_{2} \mathrm{O}$ (20 $\mathrm{mL} \times 2$ ) and brine $(20 \mathrm{~mL})$, and dried over $\mathrm{Na}_{2} \mathrm{SO}_{4}$. Filtration and evaporation gave a crude product, which was purified by silica gel column chromatography to give $\mathbf{1 k}$ as a colorless oil (818 $\mathrm{mg}, 95 \%$ yield) TLC: $\mathrm{R}_{f}=0.50$ (hexane/EtOAc $=5: 1$ )

IR (neat): 2987, 2938, 1734, 1587, 1486, 1468, 1383, 1284, 1238, 1177, $1140,1073,1023,1007,825,647 \mathrm{~cm}^{-1}$

${ }^{1} \mathrm{H}$ NMR (400 MHz, $\left.\mathrm{CDCl}_{3}\right): \delta=7.36-7.31(\mathrm{~m}, 2 \mathrm{H}), 6.75-6.71(\mathrm{~m}, 2 \mathrm{H}), 4.23$ (q, $J=7.2 \mathrm{~Hz}, 2 \mathrm{H}), 1.58(\mathrm{~s}, 6 \mathrm{H}), 1.25(\mathrm{t}, J=7.2 \mathrm{~Hz}, 3 \mathrm{H})$

${ }^{13} \mathrm{C}$ NMR $\left(125 \mathrm{MHz}_{\mathrm{CDCl}}\right): \delta=173.9,154.5,132.0,120.8,114.5,79.4$ $61.5,25.2,14.1$

HRMS (ESI): $m / z\left(\mathrm{M}+\mathrm{Na}^{+}\right)$calcd for $\mathrm{C}_{12} \mathrm{H}_{15} \mathrm{O}_{3} \mathrm{BrNa} 24$ 309.0097; found: 309.0100

\section{Ethyl 2-methyl-2-(4-(trimethylgermyl)phenoxy)propanoate (4k)}

Conditions B using ethyl 2-(4-bromophenoxy)-2-methylpropanoate $\mathbf{1 k}$ (114.9 mg, $0.40 \mathrm{mmol}$ ), $\mathrm{Pd}(\mathrm{OAc}) 2$ (20 mol \%), and ligand 5 (40 $\mathrm{mol} \%$ ) and purification of the crude product by silica gel column chromatography (hexane/EtOAc $=10: 1$ ) followed by gel permeation chromatography afforded $\mathbf{4 k}$ as a colorless oil ( $84.4 \mathrm{mg}, 65 \%$ yield).

TLC: $\mathrm{R}_{f} 0.63$ (hexane/EtOAc $=5: 1$ )

IR (neat): 2977, 2906, 1733, 1590, 1498, 1382, 1272, 1237, 1178, 1142 , $1093,1024,824,761,599,569 \mathrm{~cm}^{-1}$

${ }^{1} \mathrm{H}$ NMR (400 MHz, $\left.\mathrm{CDCl}_{3}\right): \delta=7.34-7.30(\mathrm{~m}, 2 \mathrm{H}), 6.84-6.80(\mathrm{~m}, 2 \mathrm{H})$, $4.24(\mathrm{q}, J=7.1 \mathrm{~Hz}, 2 \mathrm{H}), 1.60(\mathrm{~s}, 6 \mathrm{H}), 1.25(\mathrm{t}, J=7.1 \mathrm{~Hz}, 3 \mathrm{H}), 0.34(\mathrm{~s}, 9 \mathrm{H})$

${ }^{13} \mathrm{C}$ NMR $\left(125 \mathrm{MHz}, \mathrm{CDCl}_{3}\right): \delta=174.3,155.7,134.8,133.8,118.4,78.8$, $61.4,25.4,14.0,-1.69$

HRMS (ESI): $m / z\left(M+\mathrm{Na}^{+}\right)$calcd for $\mathrm{C}_{15} \mathrm{H}_{24} \mathrm{O}_{3}{ }^{70} \mathrm{GeNa}$ : 345.0860 ; found: 345.0862

Ethyl 5-methyl-6-oxo-8-(trimethylgermyl)-5,6-dihydro-4Hbenzo[f]imidazo[1,5-a][1,4]diazepine-3-carboxylate (4I)

Conditions B using ethyl 8-bromo-5-methyl-6-oxo-5,6-dihydro-4Hbenzo[f]imidazo[1,5- $a][1,4]$ diazepine-3-carboxylate 11 (109.3 mg, 0.30 mmol) and purification of the crude product by silica gel column chromatography (hexane/EtOAc $=1: 2$ to $1: 3$ ) and afforded $\mathbf{4 l}$ as a pale yellow solid ( $82 \mathrm{mg}, 68 \%$ yield).

TLC: $\mathrm{R}_{f}=0.36$ (toluene/EtOAc $=1: 3$ )

M.p. : $164.5-165.2^{\circ} \mathrm{C}$

IR (KBr): 3112, 2975, 2905, 1728, 1704, 1647, 1503, 1296, 1260, 1189 , $1109,1065,833,605 \mathrm{~cm}^{-1}$

${ }^{1} \mathrm{H}$ NMR (400 MHz, $\mathrm{CDCl}_{3}$ ): $\delta=8.15(\mathrm{~d}, J=1.4 \mathrm{~Hz}, 1 \mathrm{H}), 7.90(\mathrm{~s}, 1 \mathrm{H}), 7.72$ (dd, $J=7.7,1.4 \mathrm{~Hz}, 1 \mathrm{H}), 7.38$ (d, $J=7.7 \mathrm{~Hz}, 1 \mathrm{H}), 5.25-5.14(\mathrm{~m}, 1 \mathrm{H}), 4.55-$ $4.29(\mathrm{~m}, 3 \mathrm{H}), 3.26(\mathrm{~s}, 3 \mathrm{H}), 1.46(\mathrm{t}, J=7.2 \mathrm{~Hz}, 3 \mathrm{H}), 0.45(\mathrm{~s}, 9 \mathrm{H})$

${ }^{13} \mathrm{C}$ NMR (125 MHz, $\mathrm{CDCl}_{3}$ ): $\delta=166.8,162.9,144.1,137.1,136.8,135.5$, $134.8,131.8,128.5,128.0,120.9,60.8,42.2,35.7,14.3,-1.9$

HRMS (ESI): $m / z\left(\mathrm{M}+\mathrm{Na}^{+}\right)$calcd for $\mathrm{C}_{18} \mathrm{H}_{23} \mathrm{O}_{3} \mathrm{~N}_{3}{ }^{70} \mathrm{Ge} \mathrm{Na}$ : 422.0874; found: 422.0877

\section{(4-(tert-Butyl)phenyl)trimethylgermane (4m)}

Conditions B using 4-(tert-butyl)phenyl trifluoromethanesulfonate $\mathbf{2 m}$ and purification of the crude product by silica gel column chromatography (hexane/EtOAc $=30: 1$ to $10: 1$ ) afforded $4 \mathbf{m}$ as a colorless oil (63.2 mg, $50 \%$ yield).
TLC: $\mathrm{R}_{f}=0.72$ (hexane $/$ EtOAc $=8: 1$ )

M.p. : $69.2-70.0^{\circ} \mathrm{C}$

IR (KBr): 3421, 2961, 2905, 2865, 1383, 1267, 1235, 1078, 818, 760, 602, $576,552 \mathrm{~cm}^{-1}$

${ }^{1} \mathrm{H}$ NMR (400 MHz, $\left.\mathrm{CDCl}_{3}\right): \delta=7.44-7.41(\mathrm{~m}, 2 \mathrm{H}), 7.40-7.37(\mathrm{~m}, 2 \mathrm{H})$, $1.32(\mathrm{~s}, 9 \mathrm{H}), 0.37(\mathrm{~s}, 9 \mathrm{H})$

${ }^{13} \mathrm{C}$ NMR $\left(100 \mathrm{MHz}, \mathrm{CDCl}_{3}\right): \delta=151.1,138.9,132.8,124.9,34.6,31.3$, 1.79

HRMS (EI): $m / z\left(\mathrm{M}^{+}\right)$calcd for $\mathrm{C}_{13} \mathrm{H}_{22}{ }^{70} \mathrm{Ge}: 248.0964$; found: 248.0960

(4-(4-(Trimethylgermyl)phenyl)piperazin-1-yl)ethan-1-one (4n)

Conditions B using 4-(4-acetylpiperazin-1-yl)phenyl trifluoromethanesulfonate $\mathbf{2 n}$ and purification of the crude product by silica gel column chromatography (EtOAc/ $\mathrm{MeOH}=19: 1$ ) followed by gel permeation chromatography afforded $\mathbf{4 n}$ as a pink solid $(47.2 \mathrm{mg}, 29 \%$ yield).

TLC: $\mathrm{R}_{f}=0.65(\mathrm{EtOAc} / \mathrm{MeOH}=9: 1)$

M.p.: $66.7-67.8^{\circ} \mathrm{C}$

IR (KBr): 3438, 2979, 2899, 2830, 1625, 1592, 1455, 1432, 1234, 998 $\mathrm{cm}^{-1}$

${ }^{1} \mathrm{H} \mathrm{NMR}\left(500 \mathrm{MHz}, \mathrm{CDCl}_{3}\right): \delta=7.39(\mathrm{~d}, J=8.6 \mathrm{~Hz}, 2 \mathrm{H}), 6.93(\mathrm{~d}, J=8.6 \mathrm{~Hz}$, $2 \mathrm{H}), 3.77(\mathrm{t}, J=5.2 \mathrm{~Hz}, 2 \mathrm{H}), 3.62(\mathrm{t}, J=5.2 \mathrm{~Hz}, 2 \mathrm{H}), 3.20(\mathrm{t}, J=5.2 \mathrm{~Hz}, 2$ $\mathrm{H}), 3.16(\mathrm{t}, J=5.2 \mathrm{~Hz}, 2 \mathrm{H}), 2.14(\mathrm{~s}, 3 \mathrm{H}), 0.35(\mathrm{~s}, 9 \mathrm{H})$

${ }^{13} \mathrm{C} \mathrm{NMR}\left(125 \mathrm{MHz}, \mathrm{CDCl}_{3}\right): \delta=169.0,150.9,133.9,133.0,116.2,49.4$, $49.1,46.2,41.3,21.4,-1.72$

HRMS (ESI): $m / z\left(\mathrm{M}+\mathrm{Na}^{+}\right)$calcd for $\mathrm{C}_{15} \mathrm{H}_{24} \mathrm{ON}_{2}{ }^{70} \mathrm{GeNa}$ : 341.1023; found: 341.1025

\section{Trimethyl(4-nitrophenyl)germane (4o)}

Conditions B using 4-nitrophenyl trifluoromethanesulfonate 20 and KOAc instead of $\mathrm{Cs}_{2} \mathrm{CO}_{3}$, and purification of the crude product by silica gel column chromatography (hexane/EtOAc $=8: 1$ ) and gel permeation chromatography afforded $\mathbf{4 0}$ as a pale yellow solid (39.2 mg, 33\% yield).

TLC: $\mathrm{R}_{f}=0.59$ (hexane/AcOEt $=8: 1$ )

M.p. : $40.2-41.7^{\circ} \mathrm{C}$

IR (KBr): 3432, 3037, 2979, 2905, 1594, 1513, 1386, 1351, 1240, 835 $730,711,603 \mathrm{~cm}^{-1}$

${ }^{1} \mathrm{H} \mathrm{NMR}\left(400 \mathrm{MHz}, \mathrm{CDCl}_{3}\right): \delta=8.17(\mathrm{~d}, J=8.1 \mathrm{~Hz}, 2 \mathrm{H}), 7.64(\mathrm{~d}, J=8.1 \mathrm{~Hz}$, $2 \mathrm{H}), 0.44(\mathrm{~s}, 9 \mathrm{H})$

${ }^{13} \mathrm{C}$ NMR $\left(125 \mathrm{MHz}, \mathrm{CDCl}_{3}\right): \delta=152.5,148.2,133.8,122.3,-1.91$

HRMS (EI): $m / z\left(\mathrm{M}^{+}\right)$calcd for $\mathrm{C}_{9} \mathrm{H}_{13} \mathrm{O}_{2} \mathrm{~N}^{70} \mathrm{Ge}: 237.0189$; found: 237.0194

Ethyl 4-(trimethylgermyl)benzoate (4p)

Conditions B using ethyl 4-(((trifluoromethyl)sulfonyl)oxy)benzoate 2p and purification of the crude product by silica gel column chromatography (hexane/EtOAc $=20: 1$ ) followed by reverse phase column chromatography ( $\left.\mathrm{C} 18, \mathrm{H}_{2} \mathrm{O} / \mathrm{MeCN}=15 / 85\right)$ afforded $4 \mathbf{p}$ as a colorless oil (20 mg, 15\% yield).

TLC: $\mathrm{R}_{f}=0.61$ (hexane/EtOAc $=8: 1$ )

IR (neat): 2975, 2927, 2908, 1720, 1277, 1266, 1081, 602, $570 \mathrm{~cm}^{-1}$

$\left.{ }^{1} \mathrm{H} \mathrm{NMR} \mathrm{(500} \mathrm{MHz,} \mathrm{CDCl}_{3}\right): \delta=7.99(\mathrm{~d}, J=8.0 \mathrm{~Hz}, 2 \mathrm{H}), 7.55(\mathrm{~d}, J=8.0 \mathrm{~Hz}$, $2 \mathrm{H}), 4.38(\mathrm{q}, J=7.2 \mathrm{~Hz}, 2 \mathrm{H}), 1.39(\mathrm{t}, J=7.2 \mathrm{~Hz}, 3 \mathrm{H}), 0.41(\mathrm{~s}, 9 \mathrm{H})$

${ }^{13} \mathrm{C}$ NMR $\left(125 \mathrm{MHz}, \mathrm{CDCl}_{3}\right): \delta=166.9,149.2,132.9,130.2,128.6,60.9$, $14.3,-1.92$

HRMS (APCI): $m / z\left(M+\mathrm{H}^{+}\right)$calcd for $\mathrm{C}_{12} \mathrm{H}_{19} \mathrm{O}_{2}{ }^{70} \mathrm{Ge}$ : 265.0622; found: 265.0623

\section{Ethyl 3-(trimethylgermyl)benzoate (4q)}

Conditions B using ethyl 3-(((trifluoromethyl)sulfonyl)oxy)benzoate 2q and purification of the crude product by silica gel column chromatography (hexane/EtOAc $=20: 1$ ) afforded $\mathbf{4 q}$ as a colorless oil (81.4 mg, $61 \%$ yield). 
TLC: $\mathrm{R}_{f}=0.54$ (hexane/AcOEt $=8: 1$ )

IR (neat): 2976, 2906, 1719, 1410, 1365, 1261, 1172, 1116, 1071, 826 $742,602,570 \mathrm{~cm}^{-1}$

${ }^{1} \mathrm{H}$ NMR (500 MHz, $\left.\mathrm{CDCl}_{3}\right): \delta=8.14(\mathrm{~s}, 1 \mathrm{H}), 7.99(\mathrm{~d}, J=7.4 \mathrm{~Hz}, 1 \mathrm{H}), 7.66$ (d, $J=7.4 \mathrm{~Hz}, 1 \mathrm{H}$ ), 7.41 (dd, $J=7.4,7.4 \mathrm{~Hz}, 1 \mathrm{H}), 4.39$ (q, $J=7.3 \mathrm{~Hz}, 2 \mathrm{H}$ ), $1.40(\mathrm{t}, J=7.3 \mathrm{~Hz}, 3 \mathrm{H}), 0.41(\mathrm{~s}, 9 \mathrm{H})$

${ }^{13} \mathrm{C}$ NMR $\left(125 \mathrm{MHz} \mathrm{CDCl}_{3}\right): \delta=167.0,143.0,137.4,133.9,129.8,129.4$, $127.8,60.9,14.4,-1.83$

HRMS (EI): $m / z\left(\mathrm{M}^{+}\right)$calcd for $\mathrm{C}_{12} \mathrm{H}_{18} \mathrm{O}_{2}{ }^{70} \mathrm{Ge}: 264.0549$; found: 264.0551

Trimethyl(naphthalen-2-yl)germane (4r)

Conditions B using naphthalen-2-yl trifluoromethanesulfonate $2 \mathbf{r}$ and purification of the crude product by silica gel column chromatography (hexane/EtOAc $=20: 1$ ) afforded $4 \mathbf{r}$ as a colorless oil (97 mg, $79 \%$ yield).

TLC: $\mathrm{R}_{f}=0.77$ (Hexane $/$ AcOEt $=8: 1$ )

IR (neat): 3051, 2971, 2906, 1236, 1073, 815, 757, 738, 630, 600, 579, $564 \mathrm{~cm}^{-1}$

${ }^{1} \mathrm{H}$ NMR $\left(500 \mathrm{MHz}, \mathrm{CDCl}_{3}\right): \delta=7.94(\mathrm{~s}, 1 \mathrm{H}), 7.84-7.80(\mathrm{~m}, 3 \mathrm{H}), 7.57(\mathrm{~d}, J$ $=7.4 \mathrm{~Hz}, 1 \mathrm{H}), 7.49-7.44(\mathrm{~m}, 2 \mathrm{H}), 0.46(\mathrm{~s}, 9 \mathrm{H})$

${ }^{13} \mathrm{C}$ NMR $\left(100 \mathrm{MHz}, \mathrm{C}_{6} \mathrm{D}_{6}\right): \delta=133.7,127.8,127.5,127.1,123.8,121.8$, $121.8,121.3,119.9,119.8,-8.13$

HRMS (EI): $m / z\left(\mathrm{M}^{+}\right)$calcd for $\mathrm{C}_{13} \mathrm{H}_{16}{ }^{70} \mathrm{Ge}: 242.0495$; found: 242.0496

\section{Benzo[d][1,3]dioxol-5-yltrimethylgermane (4s)}

Conditions B using benzo[ $d][1,3]$ dioxol-5-yl trifluoromethanesulfonate 2s, $\mathrm{Pd}(\mathrm{OAc})_{2}$ (20 mol \%), and ligand 5 (40 mol \%) and purification of the crude product by silica gel column chromatography (hexane/EtOAc = 20:1) afforded $4 \mathbf{s}$ as a colorless oil (50.8 $\mathrm{mg}, 43 \%$ yield).

TLC: $\mathrm{R}_{f}=0.64($ Hexane $/$ EtOAc $=8: 1)$

IR (KBr): 2974, 2905, 1482, 1414, 1232, 1050, 1040, 937, 881, 825, 590 $\mathrm{cm}^{-1}$

${ }^{1} \mathrm{H}$ NMR (500 MHz, $\left.\mathrm{CDCl}_{3}\right): \delta=6.94-6.92(\mathrm{~m}, 2 \mathrm{H}), 6.86-6.83(\mathrm{~m}, 1 \mathrm{H})$, $5.93(\mathrm{~s}, 2 \mathrm{H}), 0.35(\mathrm{~s}, 9 \mathrm{H})$

${ }^{13} \mathrm{C}$ NMR $\left(100 \mathrm{MHz} \mathrm{CDCl}_{3}\right): \delta=147.7,147.4,135.4,126.3,112.5,108.6$, $100.4,-1.61$

HRMS (EI): $m / z\left(\mathrm{M}^{+}\right)$calcd for $\mathrm{C}_{10} \mathrm{H}_{14} \mathrm{O}_{2}{ }^{70} \mathrm{Ge}: 236.0236$; found: 236.0232

(8R,9S,13S)-13-Methyl-3-(trimethylgermyl)-

$6,7,8,9,11,12,13,14,15,16$-decahydro-17H-

cyclopenta $[a]$ phenanthren-17-one $(4 \mathrm{t})$

Conditions B using $(8 R, 9 S, 13 S)$-13-methyl-17-oxo7,8,9,11,12,13,14,15,16,17-decahydro-6H-cyclopenta[a]phenanthren-3yl trifluoromethanesulfonate $2 \mathrm{t}$ (402.4 mg, $1.0 \mathrm{mmol}), \mathrm{Pd}(\mathrm{OAc})_{2}(20$ mol \%), and ligand 5 (40 mol \%) at $130{ }^{\circ} \mathrm{C}$ and purification of the crude product by silica gel column chromatography (hexane/EtOAc $=20: 1$ to 10:1) afforded $\mathbf{4 t}$ as a colorless solid (174.0 mg, $47 \%$ yield).

TLC: $\mathrm{R}_{f}=0.75$ (hexane $/$ EtOAc $=7: 3$ )

M.p.: $119.3-120.2^{\circ} \mathrm{C}$

IR (KBr): 3454, 2969, 2928, 2866, 2837, 1739, 1452, 1235, 1081, 828, $603 \mathrm{~cm}^{-1}$

$\left.{ }^{1} \mathrm{H} \mathrm{NMR} \mathrm{(} \mathrm{CDCl}_{3}, 500 \mathrm{MHz}\right): \delta=7.32-7.27(\mathrm{~m}, 2 \mathrm{H}), 7.22(\mathrm{~s}, 1 \mathrm{H}), 2.94$ (dd, $J$ $=8.9,4.3 \mathrm{~Hz}, 2 \mathrm{H}), 2.51(\mathrm{dd}, J=18.9,8.6 \mathrm{~Hz}, 1 \mathrm{H}), 2.47-2.41(\mathrm{~m}, 1 \mathrm{H})$, 2.36-2.29 (m, $1 \mathrm{H}), 2.19-1.94(\mathrm{~m}, 4 \mathrm{H}), 1.68-1.59(\mathrm{~m}, 2 \mathrm{H}), 0.90(\mathrm{~s}, 3 \mathrm{H})$, $0.37(\mathrm{~s}, 9 \mathrm{H})$

${ }^{13} \mathrm{C}$ NMR $\left(125 \mathrm{MHz}, \mathrm{CDCl}_{3}\right): \delta=220.7,139.8,139.4,135.9,133.7,130.4$, $124.9,50.4,47.9,44.4,38.0,35.8,31.5,29.3,26.5,25.5,21.5,13.7,-1.84$

HRMS (ESI): $m / z\left(M+\mathrm{Na}^{+}\right)$calcd for $\mathrm{C}_{21} \mathrm{H}_{30} \mathrm{O}^{70} \mathrm{GeNa}$ : 391.1431; found: 391.1431

\section{Methyl (S)-2-((tert-butoxycarbonyl)amino)-3-(4- (trimethylgermyl)phenyl)propanoate (4u)}

Conditions B using methyl $(S)-2-(($ tert-butoxycarbonyl)amino)-3-(4(((trifluoromethyl)sulfonyl)oxy)phenyl)propanoate $\mathbf{2 u}$ and KOAc instead of $\mathrm{Cs}_{2} \mathrm{CO}_{3}$ for $62 \mathrm{~h}$, and purification of the crude product by silica gel column chromatography (hexane/EtOAc $=10: 1$ ) afforded $4 \mathbf{u}$ as a colorless solid (132.6 mg, $67 \%$ yield).

TLC: $\mathrm{R}_{f}=0.50(\mathrm{EtOAc} / \mathrm{MeOH}=9: 1)$

M.p.: $55.5-56.2^{\circ} \mathrm{C}$

IR (KBr): 3370, 2975, 1747, 1717, 1500, 1437, 1366, 1248, 1214, 1168, $825,757,600,568 \mathrm{~cm}^{-1}$

${ }^{1} \mathrm{H}$ NMR $\left(500 \mathrm{MHz} \mathrm{CDCl}_{3}, 50{ }^{\circ} \mathrm{C}\right): \delta=7.39(\mathrm{~d}, J=8.0 \mathrm{~Hz}, 2 \mathrm{H}), 7.10(\mathrm{~d}, J=$ $8.0 \mathrm{~Hz}, 2 \mathrm{H}), 4.96-4.87(\mathrm{~m}, 1 \mathrm{H}), 4.62-4.52(\mathrm{~m}, 1 \mathrm{H}), 3.71(\mathrm{~s}, 3 \mathrm{H}), 3.13-$ $3.06(\mathrm{~m}, 1 \mathrm{H}), 3.05-2.93(\mathrm{~m}, 1 \mathrm{H}), 1.40(\mathrm{~s}, 9 \mathrm{H}), 0.36(\mathrm{~s}, 9 \mathrm{H})$

${ }^{13} \mathrm{C}$ NMR (125 MHz, $\left.\mathrm{CDCl}_{3}\right): \delta=172.3,155.0,140.9,135.9,133.1,128.9$, $79.8,54.3,52.2,38.2,28.3,-1.85$

HRMS (ESI): $m / z\left(\mathrm{M}+\mathrm{Na}^{+}\right)$calcd for $\mathrm{C}_{18} \mathrm{H}_{29} \mathrm{O}_{4} \mathrm{~N}^{70} \mathrm{GeNa}$ : 416.1231; found: 416.1234

\section{Funding Information}

This work was supported in part by JSPS KAKENHI Grant Number JP15H05802 in Precisely Designed Catalysts with Customized Scaffolding.

\section{Supporting Information}

YES (this text will be updated with links prior to publication)

\section{Primary Data}

NO (this text will be deleted prior to publication)

\section{References}

(1) (a) Denmark, S. E.; Sweis, R. F. In Metal-Catalyzed Cross-Coupling Reactions, de Meijere, A.; Diederich, F. Ed.; Wiley-VCH Verlag GmbH, 2008, 163. (b) Chan, T. H.; Fleming, I. Synthesis 1979, 761. (c) Hosomi, A.; Miura, K. Bull. Chem. Soc. Jpn. 2004, 77, 835. (d) Denmark, S. E.; Ambrosi, A. Org. Process Res. Dev. 2015, 19, 982. (e) Komiyama, T.; Minami, Y.; Hiyama, T. ACS Catal. 2017, 7, 631.

(2) (a) Mitchell, T. N., In Metal-Catalyzed Cross-Coupling Reactions, de Meijere, A.; Diederich, F. Ed.; Wiley-VCH Verlag GmbH: 2008, 125. (b) Ingham, R. K.; Rosenberg, S. D.; Gilman, H. Chem. Rev. 1960, 60, 459.

(3) (a) Akiyama, T. In Main Group Metals in Organic Synthesis; Yamamoto, H.; Oshima, K., Ed.; Wiley-VCH Verlag GmbH \& Co. KGaA, Weinheim, FRG. 2004, doi: 10.1002/3527602607.ch11. (b) Quane, D.; Bottei, R. S. Chem. Rev. 1963, 63, 403 and references therein.

(4) (a) Eaborn, C.; Pande, K. C. J. Chem. Soc. 1960, 1566. (b) Moerlein, S. M. J. Chem. Soc., Perkin Trans. 1 1985, 1687. (c) Coenen, H. H.; Moerlein, S. M. J. Fluorine Chem. 1987, 36, 63. (d) Moerlein, S. M. J. Org. Chem. 1987, 52, 664.

(5) (a) Dallaire, C.; Brook, M. A. Organometallics 1990, 9, 2873. (b) Dallaire, C.; Brook, M. A. Organometallics 1993, 12, 2332.

(6) (a) Boyer, I. J. Toxicology 1989, 55, 253. (b) Arylgermanes are gerneally less toxic even compared with organosilanes: Lukevics, E.; Ignatovich, L. Appl. Organometal. Chem. 1992, 6, 113.

(7) (a) Spivey, A. C.; Gripton, C. J.; Noban, C.; Parr, N. J. Synlett 2005, 2167. (b) Zhang, Q.; Liu, C.; Shi, J.; Xu, Q.; Jin, L.; Zhao, C.; Zhang, T. Synlett 2016, 27, 1945. (c) Ozaki, K.; Matsuoka, W.; Ito, H.; Itami, K. Org. Lett. 2017, 19, 1930, (d) Ozaki, K.; Murai, K.; Matsuoka, W.; Kawasumi, K.; Ito, H.; Itami, K. Angew. Chem. Int. Ed. 2017, 56, 1361.

(8) Cross-coupling reactions of arylgermane derivatives: (a) Kosugi, M.; Tanji, T.; Tanaka, Y.; Yoshida, A.; Fugami, K.; Kameyama, M.; Migita, T. J. Organomet. Chem. 1996, 508, 255. (b) Faller, J. W.; Kultyshev, R. G. Organometallics 2002, 21, 5911. (c) Nakamura, T.; Kinoshita, H.; Shinokubo, H.; Oshima, K. Org. Lett. 2002, 4, 3165. (d) Enokido, T.; Fugami, K.; Endo, M.; Kameyama, M.; Kosugi, M. Adv. Synth. Catal. 2004, 346, 1685. (e) Endo, M.; Fugami, K.; 
Enokido, T.; Sano, H.; Kosugi, M. Adv. Synth. Catal. 2007, 349, 1025. (f) Spivey, A. C.; Tseng, C.-C.; Hannah, J. P.; Gripton, C. J. G.; de Fraine, P.; Parr, N. J.; Scicinski, J. J. Chem. Commun. 2007, 2926. (g) Pitteloud, J.-P.; Zhang, Z.-T.; Liang, Y.; Cabrera, L.; Wnuk, S. F. J. Org. Chem. 2010, 75, 8199. (g) Zhang, Z.-T.; Pitteloud, J.-P.; Cabrera, L.; Liang, Y.; Toribio, M.; Wnuk, S. F. Org. Lett. 2010, 12, 816.

(9) (a) Matsumoto, H.; Nagashima, S.; Yoshihiro, K.; Nagai, Y. J. Organomet. Chem. 1975, 85. C1. (b) Azarian, D.; Dua, S. S.; Eaborn, C.; Walton, D. R. M. J. Organomet. Chem. 1976, 117. C55. (c) Matsumoto, H.; Yoshihiro, K.; Nagashima, S.; Watanabe, H.; Nagai, Y. J. Organomet. Chem. 1977, 128, 409. (d) Eaborn, C.; Griffiths, R. W.; Pidcock, A. J. Organomet. Chem. 1982, 225, 331. (e) Hatanaka, Y.; Hiyama, T. Tetrahedron Lett. 1987, 28, 4715. (f) Gooßen, L. J.; Ferwanah, A.-R. S.; Synlett 2000, 1801. (g) Shirakawa, E.; Kurahashi, T.; Yoshida, H.; Hiyama, T. Chem. Commun. 2000, 1895. (h) Denmark, S. E.; Kallemeyn, J. M. Org. Lett. 2003, 5, 3483. (i) Iwasawa, T.; Komano, T.; Tajima, A.; Tokunaga, M.; Obora, Y.; Fujihara, T.; Tsuji, Y. Organometallics 2006, 25, 4665. (j) McNeill, E.; Barder, T. E.; Buchwald, S. L. Org. Lett. 2007, 9, 3785.

(10) (a) Murata, M.; Suzuki, K.; Watanabe, S.; Masuda, Y. J. Org. Chem. 1997, 62, 8569. (b) Manoso, A. S.; DeShong, P. J. Org. Chem. 2001, 66, 7449. (c) Murata, M.; Ishikura, M.; Nagata, M.; Watanabe, S.; Masuda, Y. Org. Lett. 2002, 4, 1843. (d) Yamanoi, Y. J. Org. Chem. 2005, 70, 9607. (e) Hamze, A.; Provot, O.; Alami, M.; Brion, J.-D. Org. Lett. 2006, 8, 931. (e) Yamanoi, Y.; Nishihara, H. Tetrahedron Lett. 2006, 47, 7157. (g) Murata, M.; Yamasaki, H.; Ueta, T.; Nagata,
M.; Ishikura, M.; Watanabe, S.; Masuda, Y. Tetrahedron 2007, 63, 4087. (h) Murata, M.; Yamasaki, H.; Uogishi, K.; Watanabe, S.; Masuda, Y. Synthesis 2007, 2944. (i) Yamanoi, Y.; Taira, T.; Sato, J.i.; Nakamula, I.; Nishihara, H. Org. Lett. 2007, 9, 4543. (j) Yamanoi, Y.; Nishihara, H. J. Org. Chem. 2008, 73, 6671. (k) Lesbani, A.; Kondo, H.; Yabusaki, Y.; Nakai, M.; Yamanoi, Y.; Nishihara, H. Chem Eur. J. 2010, 16, 13519. (l) Yamanoi, Y.; Sendo, J.; Kobayashi, T.; Maeda, H.; Yabusaki, Y.; Miyachi, M.; Sakamoto, R.; Nishihara, H. J. Am. Chem. Soc. 2012, 134, 20433. (m) Chen, L.; Huang, J.-B.; Xu, Z.; Zheng, Z.-J.; Yang, K.-F.; Cui, Y.-M.; Cao, J.; Xu, L.-W. RSC Adv. 2016, 6, 67113. (n) Xu, Z.; Xu, J.-Z.; Zhang, J.; Zheng, Z.-J.; Cao, J.; Cui, Y.M.; Xu, L.-W. Chem. Asian J. 2017, 12, 1749.

(11) Reddy, P. N.; Hayashi, T.; Tanaka, M. Chem. Lett. 1991, 20, 677.

(12) Goodson, F. E.; Wallow, T. I.; Novak, B. M. J. Am. Chem. Soc. 1997, 119,12441 and references therein.

(13) Grundy, S. M.; Ahrens, E. H., Jr.; Salen, G.; Schreibman, P. H.; Nestel, P. J. J. Lipid Res. 1972, 13, 531.

(14) Yang, J.; Teng, Y.; Ara, S.; Rallapalli, S.; Cook, J. M. Synthesis 2009, 1036.

(15) Taylor, N. J.; Emer, E.; Preshlock, S.; Schedler, M.; Tredwell, M.; Verhoog, S.; Mercier, J.; Genicot, C.; Gouverneur, V. J. Am. Chem. Soc. 2017, 139, 8267.

(16) Zanon, J.; Klapars, A.; Buchwald, S. L. J. Am. Chem. Soc. 2003, 125, 2890.

(17) Krajewski, K.; Zhang, Y.; Parrish, D.; Deschamps, J.; Rollera, P. P.; Pathak, V. K. Bioorg. Med. Chem. Lett. 2006, 16, 3034. 